\title{
Redescription of Skrjabinus skrjabini and validity reassessment of selected species of Skrjabinus (Digenea, Dicrocoeliidae)
}

\author{
J. SITKO
}

Comenius Museum, Horní nám. 7, 75011 Přerov, Czech Republic, E-mail: sitko@prerovmuzeum.cz

\begin{abstract}
Summary
Four specimens of Skrjabinus skrjabini, were isolated from two out of 93 red-backed shrikes (Lanius collurio) examined during $1962-2012$. The species have been re-described and the generic diagnosis amended. Eight species of the genus have been validated: S. aenigma, $S$. indicus, $S$. latus, S. pancreaticus, S. rarus, S. skrjabini, S. similis, and $S$. sp. of Oshmarin (1970). Others have been reclassified as Platynosomum ( $P$. dicruri, P. gracile, and P. talischense with synonyms $P$. butei and $S$. sp. of Oshmarin (1963)) and Zonorchis (Z. francolini, and Z. petiolatus with synonyms S. biliosus, S. gvozdevi, S. popovi). Skrjabinus petrovi is a synonym of Brachydistomum ventricosum. Lubens lubens determited by Bhuta \& Khan (1975) is a synonym of $S$. aenigma.
\end{abstract}

Keywords: Skrjabinus; Platynosomum; Zonorchis; Dicrocoeliidae; Digenea; birds

\section{Introduction}

Skrjabinus skrjabini (Issaitschikow, 1920) Bhalerao, 1936 is a rare parasite of insectivorous passerine bird Lanius collurio Linnaeus, 1758 in Europe. The original description by Issaitschikow (1920) is incomplete; dimensions of the ventral sucker are missing. The species has not been found since, and the original material has been lost. At present, 19 species are placed in the genus Skrjabinus Bhalerao, 1936. A considerable number of them are misclassified due to the incomplete description of the type species. They are exclusively parasites of birds; species described from mammals do not possess typical characters of the genus. Pojmanska (2008) wrongly classified Zonorchis as a synonym of Skrjabinus and mistook the figure of S. similis Shtrom, 1940 (it does not correspond to the original figure). Zonorchis differs from Skrjabinus in elongated body shape, position of reproductive organs (testes nearly touch one another, and ovary is often touching tes- tes, whereas in Skrjabinus testes are distant one from another and ovary is separated from testes by a large number of uterine coils). The main character is the ventral suckermassive in Zonorchis, ocuppying the whole body width and thickess, while weakly developed in Skrjabinus, on body surface only.

The present study aims to redescribe the type species of Skrjabinus, amend the genus diagnosis and reassess the classification of selected species.

\section{Material and methods}

During the years $1962-2012$, four specimens of $S$. skrjabini were found in two out of $93 \mathrm{~L}$. collurio examined. Dead birds intended for museum collections were examined. Morphological variability was studied in living as well as fixed material (fixed by hot $70 \%$ ethanol). After staining with borax carmine worms were mounted in $\mathrm{Ca}$ nada balsam. All dimensions are in $\mu \mathrm{m}$.

Comparative morphological study was done using slides of the following species (in brackets number of specimens studied) deposited in the collection of the Comenius $\mathrm{Mu}-$ seum in Přerov, Czech Republic: Brachydistomum ventricosum (Rudolphi, 1802) (358), B. olssoni (Railliet, 1900) (109), Conspicuum acuminatum (Nicoll, 1915) (1), Euparadistomum falconi Borgarenko, 1972 (9), Lubens lubens (Braun, 1901) (1), Lutztrema attenuatum (Dujardin, 1845) (501), Lyperosomum alaudae (Shtrom \& Sondak, 1935) (7), L. collurionis (Skrjabin \& Issaitschikow, 1927) (187), L. longicauda (Rudolphi, 1809) Looss, 1899 (5), L. pawlowskyi (Shtrom, 1928) (1), Platynosomum alectoris Nöller \& Enigk, 1933 (1), P. illiciens (Braun, 1901) (46), P. tuvensis Krasnolobova \& Timofeeva, 1968 (18), Stromitrema koshewnikowi (Skrjabin \& Massino, 1925) (50), Zonorchis clathratus Deslongschamps, 1824 (106), Z. petiolatus (Railliet, 1900) (158). In addition, the following species were used: Conspicuum conspicuum Faria, 1912 
Coll. No: 36741 and Ugandalubens banagei Goodman, 1988 Coll. No: 76944 deposited in the USNM Helminthological Collection Beltsville, Washington, USA; Zonorchis microrchis Travassos, 1944, Coll. No 2.661 deposited in the Instituto Oswaldo Cruz, Rio de Janeiro, Brasil, and Lyperosomum pawlowskyi (Strom, 1928) (50) deposited in the Institute of Parasitology, Slovak Academy of Science, Košice, Slovak Republic. In addition, I studied trematodes of the family Dicrocoeliidae deposited in the Natural History Museum, University of Wroclaw; Museum and Institute of Zoology, Polish Academy of Science, Warszawa, Poland; Institute of Parasitology, Russian Academy of Science, Moskva, Russia; Institute of Parasitology, Ukraine Academy of Science, Kiev, Ukraine; Institute of Parasitology, Czech Academy of Science, České Budějovice, Czech Republic, and in the Institute of Parasitology, Slovak Academy of Science, Košice, Slovak Republic. Unfortunately, these collections do not host any additional species of the subfamily Leipertrematinae Yamaguti, 1958 to those deposited in the Comenius Museum. Based on data in literature and on websites, specimens of Skrjabinus spp. parasitizing birds are not deposited in museum collections; therefore, I could only use published data for the revision. To complete the morphological observations, I also studied impact of various fixation methods on body shape of dicrocoeliids in Brachydistomum ventricosum, Lutztrema attenuatum, Zonorchis clathratus, Z. petiolatus, and Platynosomum illiciens (Sitko, 1995; Sitko \& Okulewicz, 2002; Sitko et al.; 2000).

\section{Results}

Generic diagnosis of Skrjabinus Bhalerao, 1936

Dicrocoeliidae, Leipertrematinae.

Body widely lanceolate with pointed caudal extremity. Tegument unspined. Suckers located in first third of body, very close one to another, of the same length. Oral sucker subterminal, elongate-oval. Ventral sucker lentiform, rarely broadly oval, considerably wider than oral sucker, weakly developed. Pharynx well developed, situated at level of oral sucker or just posterior to it. Oesophagus very short. Intestinal bifurcation shortly posterior to pharynx; caeca relatively narrow, running alongside body edges, ending blindly near pointed posterior extremity. Testes smooth, oval, relatively small, located laterally at level of ventral sucker or slightly posterior to it. Cirrus-sac elongate-oval, running from caecal bifurcation to region of pharynx, where it opens through genital pore to body surface. Cirrus short, smooth. Ovary lateral, in large distance from testes, at end of second third of body. Uterus forming large number of coils and filling body behind reproductive organs as well as in region of ventral sucker. Vitelline bands very long, running from posterior margin of testes to $3 / 4$ of body length, composed of small follicles. Excretory system Y-shaped. Parasites of gall blader of passeriform birds of Asia and Europe, exceptionally found in Gruiformes and Galliformes in Asia.

Redescription of the type species Skrjabinus skrjabini

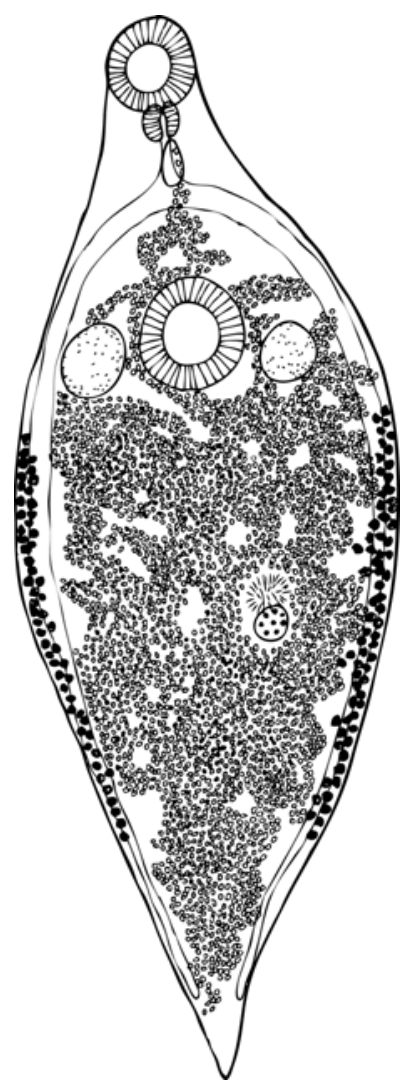

Fig. 1. Skrjabinus skrjabini Issaitschikow, 1920

(Issaitschikow, 1920) Shtrom, 1940 (Fig. 1).

Body length $3.486-4.633 \mathrm{~mm}$, lanceolate or leaf-like, widening from oral to ventral sucker. Widest at level of anterior margin of vitelline bands $(1.514-1.857 \mathrm{~mm})$, tapering posteriorly; posterior extremity pointed, creating appendage. Body smooth, unspined. Suckers in anterior third of body, very close one to another. Oral sucker subterminal, mostly elongate-oval $(377-464 \times 348-406)$. Ventral sucker very weakly developed, on body surface. Suckers of equal length, ventral sucker remarkably wider, lentiform, $368-536 \times 493-536$. Ratio of sucker lengths $0.93-1.23$, widths $1.21-1.45$.Pharynx in region of oral sucker, broadly oval, $128-139 \times 157-186$. Praepharynx not formed. Oesophagus very short. Caeca relatively narrow, very distant from each other, ending blindly near the pointed posterior extremity. Testes small, smooth, oval or spherical, located laterally at level of ventral sucker or just posterior to it, but not reaching region of ventral sucker, separated from it by large number of uterine coils. Left testis $184-264 \times 184-261$, right testis $184-302 \times 184-$ 290. Cirrus-sac elongate-oval, $209-350 \times 92-128$, beginning usually in region of intestinal bifurcation. Genital opening in region of pharynx. Cirrus short, smooth. Ovary smooth, spherical or broadly oval, lateral, most often in second third of body, $184-232 \times 230-252$, separated from testes by many uterine coils. Mehlis' gland spherical or broadly oval, very well developed, often slightly larger than ovary, $145-184 \times 157-203$. Located close to ovary, both organs often slightly overlap. Vitelline bands lateral, 
Table1. Comparison of the measurements of Lubens lubens (Braun, 1901), L. lubens sensu Bhutta \& Khan, 1975 and Skrjabinus aenigma Gvozdev, 1956

\begin{tabular}{lccc}
\hline & \multicolumn{2}{c}{ Lubens lubens } & Skrjabinus aenigma \\
& Travassos (1944) & Bhutta \& Khan (1975) & Gvozdev (1956) \\
\hline Body length & $7.600-8.300$ & $1.908-2.424$ & $4.600-5.700$ \\
$\quad$ width & $3.900-4.300$ & $757-1.363$ & $1.700-2.100$ \\
Oral sucker & $780 \times 780$ & $313-392 \times 294-343$ & $480-520 \times 480-520$ \\
Pharynx & $200-240 \times 240-280$ & $88-117 \times 117-147$ & $200 \times 220-240$ \\
Ventral sucker & $830 \times 830$ & $323-382 \times 352-421$ & $480-520 \times 480-520$ \\
Ratio of suckers & $1-1.2$ & - & - \\
Vitellarium longer & 4.300 & - & 3.000 \\
$\quad$ shorter & 3.640 & - & 1.700 \\
Ovary left & $280 \times 07-127 \times 137-186$ & $280-400 \times 360-480$ \\
Testes left & $240 \times 280-410$ & $1070-280 \times 220-320$ \\
Testes right & $280-330 \times 120$ & $137-196 \times 176-225$ & $220-280 \times 220-320$ \\
Cirrus pouch & $240 \times 240$ & $71-102 \times 25-30$ & $280 \times 120$ \\
Mehlis gland & $30-35 \times 22-25$ & - & $140-240 \times 140-240$ \\
Eggs & & $25-30 \times 13-20$ & $30-34 \times 17-20$ \\
\hline
\end{tabular}

from posterior margin of testes to $3 / 4$ of body length, ocuppying nearly half of body length: longer branch $1.543-$ 1.943, shorter branch $1.257-1.714$. Their ducts connect at posterior margin of ovary and form small vitelline sac. Vitelline bands composed of many follicles that are most often broadly oval or spherical and placed in $2-4$ rows behind each other. Most follicles extracaecal, very well developed. Uterine coils progress from ovary to pointed posterior extremity, then back to ovary. Space around ovary and Mehlis' gland remains empty. Biggest part of uterus located among ovary, testes and vitelline bands, where eggs fill the whole space. Eggs also fill space between testes and intestinal bifurcation and obscure ventral sucker. Particular uterine coils reach posterior margins of testes but do not cover them. Uterine coils end in region of intestinal bifurcation; the only branch continues from here, ending in region of pharynx by female genital opening. Excretory system Y-shaped. Eggs small, brown-black with thick shell, $32-36 \times 22-25$.

Remarks: Ventral sucker is well visible in living trematodes (in young specimens with an underdeveloped uterus or in very old specimens with only few eggs left) and in fixed specimens in reflected light of the stereomicroscope as long as the trematodes are in ethanol. After transfer into xylene and Canada balsam ventral sucker disappears and can be poorly distinguishable on a mount. Ventral sucker can also be poorely visible due to being obscured by uterine coils filled with eggs.

Taxonomic summary

Type host: Lanius collurio Linnaeus, 1758. Type locality: Záhlinice, 6770, (49 $\left.17^{\prime} 06^{\prime \prime N} / 17^{\circ} 28^{\prime} 41^{\prime \prime E}\right)$, Czech Republic. Site of infection: gall bladder. Prevalence $2.0 \%$, intensity of infection 2, mean intensity 2, abundance 0.05 . Voucher specimen deposited in Comenius Museum in Přerov, Czech Republic, accession number P-P-1859/21.

\section{Discussion}

Species composition of the genus is revised based on stu- dies published in books and journals. Species list published on https://insects.tamu.edu/research/collection/hallan/test/ Platyhelminthes/Family/Dicrocoeliidae.txt is mechanically based on the work by Pojmanska (2008), without knowledge of specialist literature and without detailed evaluation of the species of the family Dicrocoeliidae; therefore, I do not accept it. The authors use many synonyms, transfer species from one genus to another withou any explanation, and there are mistakes in species names. For these reasons, this list is of limited use only.

Skrjabinus aenigma Gvozdev, 1956, S. indicus Jaiswal, 1957, S. latus Shtrom, 1940, S. pancreaticus Oshmarin, 1971, S. rarus Shtrom, 1940, S. similis Shtrom, 1940, and $S$. sp. of Oshmarin (1970) are characterised by lanceolate body shape, suckers of approximately equal size close to each other, small testes in region of ventral sucker, ovary separated from testes by multiple uterine coils, and by long vitelline bands beginning at level of ventral sucker and reaching two-thirds of body length. These characteristics correspond to the genus Skrjabinus.

Lubens lubens (Braun, 1901) sensu Bhutta \& Khan (1975) is not deposited in museum collections. After having studied L. lubens in the Comenius Museum collection I found out that the assignation of the above finding is incorrect. The species was originally described from South America; it is a large species with elongate-oval body and large ventral sucker. Testes are located posterior to ventral sucker, uterus posterior to ovary forms many coils that fill $3 / 4$ of body length. However, the finding described by Bhutta and Khan (1975) has lanceolate body, suckers of approximately equal size, close to each other; small testes in region of ventral sucker, and relatively short uterus. All these characters correspond to Skrjabinus aenigma described by Gvozdev (1956) from the same host in Kazakhstan. Lubens lubens determined by Bhuta \& Khan (1975) is therefore a synonym of $S$. aenigma. Comparison of the measurements of L. lubens (Braun, 1901), L. lubens (Braun, 1901) sensu Bhutta \& Khan, 1975 and S. aenigma Gvosdev, 1956 is in Table 1.

Skrjabinus biliosus Shtrom, 1940, S. gvozdevi Panin, 1977, 
Table 2. Comparison of the measurements of Zonorchis petiolatus (Railliet, 1900), Skrjabinus biliosus Shtrom, 1940, S. gvozdevi Panin, 1977, S. popovi Kasimov, 1952

\begin{tabular}{|c|c|c|c|c|}
\hline & $\begin{array}{c}\text { S. biliosus } \\
\text { Shtrom (1940) }\end{array}$ & $\begin{array}{c}\text { S. gvozdevi } \\
\text { Panin (1977) }\end{array}$ & $\begin{array}{c}\text { S. popovi } \\
\text { Kasimov (1952) }\end{array}$ & $\begin{array}{l}\text { Z. petiolatus, own material } \\
\qquad \mathrm{n}=40\end{array}$ \\
\hline Body length & 5.400 & 4.800 & 4.300 & $4.576-8.867$ \\
\hline width & 1.640 & 1.500 & 1.050 & $1.120-2.000$ \\
\hline Oral sucker & $470 \times 560$ & $330-350 \times 260-400$ & $280 \times 310$ & $220-476 \times 302-551$ \\
\hline Pharynx & $170 \times 160$ & $176 \times 192$ & $105 \times 105$ & $110-203 \times 128-232$ \\
\hline Ventral sucker & $560 \times 530$ & $620-650 \times 620-650$ & $520 \times 520$ & $492-920 \times 460-920$ \\
\hline Ratio of suckers & - & $1: 1.60-1.80$ & - & $1: 1.32-2.34$ \\
\hline Vitellarium longer & - & $1.120-1.560$ & 1.570 & $1.371-3.804$ \\
\hline shorter & - & $976-1.080$ & 1.150 & $1.029-3.432$ \\
\hline Ovary & $280 \times 310$ & $200-220 \times 220-240$ & $168 \times 230$ & $174-331 \times 174-432$ \\
\hline Testes left & $510 \times 400$ & $300-400 \times 240-350$ & $0.126 \times 0.210$ & $276-662 \times 202-644$ \\
\hline Testes right & $510 \times 340$ & $320-380 \times 400$ & $178 \times 241$ & $276-643 \times 202-653$ \\
\hline Cirrus pouch & $310 \times 110$ & $560 \times 140$ & $210 \times 168$ & $406-828 \times 70-230$ \\
\hline Mehlis gland & - & $145-184 \times 157-203$ & - & $87-258 \times 92-322$ \\
\hline Eggs & $28-32 \times 17-22$ & $40 \times 23$ & $31 \times 21$ & $28-30 \times 20-22$ \\
\hline
\end{tabular}

and S. popovi Kasimov, 1952 are not deposited in museum collections, thus can be evaluated based on literary data only. These species do not possess characters corresponding to the generic diagnosis of Skrjabinus. They differ in elongated body shape, large, well developed ventral sucker located in large distance from oral sucker, testes placed posterior to ventral sucker, ovary located just next to testes. During evaluation of the morphometric characters of $S$. biliosus, S. gvozdevi and S. popovi and their comparison with my own numerous specimens of Zonorchis petiolatus (frequent parasite of passeriforms of the families Corvidae, Sturnidae and Turdidae in the Palaearctic Region), I did not find any differences; therefore, I consider S. biliosus, $S$. gvozdevi and $S$. popovi synonyms of $Z$. petiolatus. Sadykhov (1970) reported S. popovi also from Alauda arvensis L. and Porzana paykullii Ljungh. After having studied my findings from Alauda arvensis and Porzana sp.
I believe that the determination is incorrect. The author probably determined two different species of the genus Lyperosomum Looss, 1899 as S. popovi. He did not give description or depiction of his findings, and the material has not been preserved, though; therefore, it is not possible to perform a re-determination. However, for the abovementioned reasons, Alauda arvensis and P. paykullii cannot be listed among the host species of $Z$. petiolatus. Comparison of the measurements of S. biliosus Shtrom, 1940, S. gvozdevi Panin, 1977, S. popovi Kasimov, 1952 and $Z$. petiolatus (Railliet, 1900) is in Table 2.

Skrjabinus francolini Karyakarte, 1970 is characterised by elongated body, large, strongly developed ventral sucker much larger than oral sucker, suckers very far from each other, testes placed posterior to ventral sucker, small distance between ovary and testes, and by very long vitelline bands. These are characters of the genus Zonorchis; there-

Table 3. Comparison of the measurements of Platynosomum talischense (Kasimov, Vaidova \& Feyzullaev, 1959), Skrjabinus sp. of Oshmarin, 1963 and Platynosomum butei Zhelyazkova-Paspaleva, 1962

\begin{tabular}{|c|c|c|c|}
\hline & $\begin{array}{l}\text { P. butei Zhelyazkova-Paspaleva } \\
\text { (1962) }\end{array}$ & $\begin{array}{c}\text { P. talischense Kasimov et al. } \\
\text { (1959) }\end{array}$ & $\begin{array}{c}\text { Skrjabinus sp. of Oshmarin } \\
\text { (1963) }\end{array}$ \\
\hline Body length & $5.000-6.000$ & $3.000-5.000$ & 2.250 \\
\hline width & $1.500-1.800$ & $1.200-2.100$ & 1.520 \\
\hline Oral sucker & $450 \times 230$ & $300-450 \times 260-510$ & $260 \times 320$ \\
\hline Pharynx & $130 \times 150$ & $120-140 \times 150$ & $110 \times 100$ \\
\hline Ventral sucker & $600 \times 500$ & $600-660 \times 720-780$ & - \\
\hline Ratio of suckers & - & $1: 1.60-1.70$ & - \\
\hline Vitellarium longer & 850 & - & - \\
\hline shorter & 550 & - & - \\
\hline Ovary & $380 \times 220$ & $130-300 \times 150-480$ & - \\
\hline Testes left & $250 \times 170$ & $240-540 \times 300-420$ & - \\
\hline Testes right & $200 \times 140$ & $240-540 \times 300-420$ & - \\
\hline Cirrus-sac & $250 \times 100$ & $390 \times 140$ & - \\
\hline Cirrus pouch & - & $145-184 \times 157-203$ & - \\
\hline Eggs & $40 \times 20$ & $42-51 \times 24-30$ & $28-40 \times 20-22$ \\
\hline
\end{tabular}


Table 4. Comparison of the measurements of Brachydistomum ventricosum Rudolphi, 1809 and Skrjabinus petrovi Ayupov, 1951

S. petrovi Ayupov (1951) $\quad$ B. ventricosum, own material, $\mathrm{n}=40$

\begin{tabular}{lcc}
\hline Body length & $4.590-6.239$ & $1.943-6.006$ \\
$\quad$ width & $1.156-1.649$ & $0.314-1.114$ \\
Oral sucker & $221-442 \times 221-408$ & $180-422 \times 60-144$ \\
Pharynx & $102-170 \times 102-136$ & $128-139 \times 60-132$ \\
Ventral sucker & $510-629 \times 578-765$ & $210-540 \times 252-600$ \\
Ratio of suckers & - & $1: 0.89-3.36$ \\
Vitellarium longer & $680-1.309$ & $210-1.200$ \\
shorter & $663-1.258$ & $210-914$ \\
Ovary & $187 \times 376$ & $120-301 \times 150-390$ \\
Testes left & $599-1.190 \times 510-748$ & $180-867 \times 240-1.108$ \\
Testes right & $595-1.105 \times 459-799$ & $168-663 \times 180-1.060$ \\
Cirrus pouch & $289-476 \times 153-0.221$ & $120-422 \times 90-216$ \\
Mehlis gland & - & $0.102-0.132 \times 0.108-0.222$ \\
Eggs & $34-63 \times 26-45$ & $51-54 \times 31-38$ \\
\hline
\end{tabular}

fore, I remove this species from Skrjabinus and transfer it to Zonorchis as Z. francolini (Karyakarte, 1970) n. comb. Skrjabinus lanciformis Oshmarin, 1952 - after having studied my own material from the birds of prey and the original description (Oshmarin (1952) in Skrjabin \& Evranova (1952)) that states: "Trematodes have long oval body, large ventral sucker that is massively developed and much larger than oral sucker, testes are posterior to ventral sucker, ovary is in the proximity of testes, vitelline bands are strongly developed," I agree with the opinion of Odening (1964) and Yamaguti (1971) to place the taxon in the genus Zonorchis as Z. lanciformis.

Skrjabinus dicruri Nguyen Thi Le, 1968 and S. gracilis Nguyen Thi Le, 1968 are distinguished by long, oval body, suckers of nearly equal size, large oval testes occupying whole body width behind ventral sucker, ovary touching testes, and by very short vitelline bands beginning at posterior margin of testes. These are characters of the genus Platynosomum; therefore, I transfer the species to this genus as Platynosomum dicruri (Nguyen Thi Le, 1968) $\mathrm{n}$. comb. and P. gracile (Nguyen Thi Le, 1968) n. comb.

Skrjabinus talischensis Kasimov, Vajdova \& Feyzullaev, 1959 (syn. Concinnum talischensis Kasimov, Vajdova \& Feyzullaev, 1959, S. talischensis sensu Panin (1984); Concinnum butei Zhelyazkova-Paspaleva, 1962; Skrjabinus sp. of Oshmarin (1963)) is not deposited in collections, therefore the findings cannot be revised. After comparison with my findings of Platynosomum illiciens from Falco tinnunculus fixed by various methods I classify the species in the genus Platynosomum as $P$. talischense (Kasimov, Vaidova \& Feyzullaev, 1959) n. comb. This species is characterised by large number of uterine coils posterior to the ventral sucker. Based on my study of the influence of the fixation method on body shape in P. illiciens I assume that the authors described old specimens fixed alive using disproportionately strong pressure and thus changing the body shape from elongate-oval to broadly oval. Comparison of the measurements of $P$. talischense (Kasimov, Vaidova \& Feyzullaev, 1959), S. sp. of Oshmarin (1963) and P. butei Zhelyazkova-Paspaleva, 1962 is in Table 3.

Skrjabinus kalmikensis Skrjabin \& Issaitschikow, 1927 is characterised by broadly oval body, large, well developed ventral sucker, reproductive organs located close to each other, and by long vitelline bands. I agree with the opinion of Yamaguti (1971) that it should be placed as a valid taxon in the genus Conspicuum Bhalerao, 1936. Classification of this species in the genus Lyperosomum by Odening (1964) or in the genus Skrjabinus by Panin (1984) is incorrect.

With regard to the species S. lanceatus Shtrom 1940 I agree with the view of Odening (1964) and Yamaguti (1971) to place it in the genus Conspicuum.

Skrjabinus petrovi Ayupov, 1951 is not deposited in museum collections and the finding therefore cannot be revised. It has elongate-oval body, lentiform ventral sucker, large testes occupying whole body width, considerably smaller ovary placed medially, vitelline bands very short, beginning posterior to ovary, and uterus in two formations: in region of ventral sucker and posterior to ovary. Based on these characters and after having studied my own material of several hundreds of specimens of Brachydistomum ventricosum (Rudolphi, 1809) I came to the conclusion that these taxa are conspecific morphologically and in dimensions. Therefore, I assess $S$. petrovi as a synonym of $B$. ventricosum. The species has been reported from many host species, particularly birds of the orders Passeriformes and Galliformes from the Holarctic Region (Sitko \& Okulewicz 2002). Comparison of the measurements of $B$. ventricosum Rudolphi, 1809 and $S$. petrovi Ayupov is in Table 4.

\section{Conclusion}

Body shape of the Dicrocoeliidae considerably changes 
depending on age of the individual, and on method and speed of fixation. The trematodes live for very long time, longer than six months (I found Stromitrema koshewnikowi that does not develop in Europe in Hirundo rustica in September, i.e. six months after possible infection). During such a long lifespan the shape of the body, and thus also the position of the reproductive organs, changes. During the fixation of living worms the body contracts and is much wider than in worms fixed after dissection of frozen birds. In trematodes of other families the changes in body shape are not so distinctive. This lack of knowledge and missing description of ventral sucker in the type species caused problems in the systematics of the family and incorrect determinations. In addition, Skrjabinus is rarely brought from the wintering sites (prevalence lower than $5 \%$ ). Descriptions of some species are based on findings of several specimens that are not deposited in museum collections; therefore, it was not possible to comment in detail on the species composition of the genus.

\section{Acknowledgements}

I would like to thank to the curators of the collections mentioned above for loans or possibility to study the material. The study was supported by the Grant of Ministry Culture Czech Republic, Project DE 07P04OMG007.

\section{References}

Ayupov, CH. V. (1951): [New Trematode from bille duckt of pigeon - Skrjabinus petrovi sp.n.] Trudy Bashkirskoi Nauchnoissledovatel'skoi Veterinarnoy Opitnoy Stantsii, 6: 112 - 115 (In Russian)

BhutTA, M. S., KHAN, D. (1975): Digenetic Trematodes of Vertebrates from Pakistan. Bulletin of Department of Zoology of University of Panjab (New Series), 8, 1 - 175

BYKHOVSKAYA-PAVLOVSKAYA, I. E. 1962. [Trematodes of Birds of the Fauna of the USSR.] Nauka Moscow, 407 pp. (In Russian)

GvozdeV, E. V. (1956): [Parasitic Worms in Common Quail from near Alma-Ata.] Trudy Instituta Zoologii Akademii Nauk Kazakhskoi SSR, 5: 77 - 83 (In Russian) ISSAITSCHIKOW, I. M. (1920): [New representative of the genus Eurytrema Looss.] Izvestya Donskogo Veterinarnogo Instituta, 1(2): 1 - 11 (In Russian)

KASIMOV, G. B. (1952): [Skjabinus popovi n.sp. - new Trematode from Tetraogallus caucasicus.] Trudy Gelmintologicheskoi Laboratorii Akademii Nauk SSSR, 6: 232 234 (In Russian)

Kasimov, G. B., Vaidova, S. M., Feysullaev, N. A. (1959): [New species of Trematode Concinnum talishiensis nov. sp. (Fam. Dicrocoeliidae) from the liver in Marsh Harrier (Circus aeruginosus) from Azerbaian.] Doklady Akademii Nauk Azerbaidzhanskoi SSR, 15: 1057 1059 (In Russian)

KuRASHVILI, B. E. (1957): [Helminths of commercially important game birds of Georgia from faunistic and ecological standpoind.] Nauka Moscow, 434 pp. (In Rusian) ODENING, K. (1964): Dicrocoelioidea and Microphalloidea (Trematoda: Plagiorchata) aus Vögeln des Berliner Tierparks. Mitteilungen aus dem Zoologischen Museum Berlin, 40 (2): 147 - 168

OSHMARIN, P. G. (1963): [Helminths in Mammals and Birds from Primorsk area.] Nauka Moscow, 322 pp. (In Russian)

PANIN, V. YA. (1984): [Dicrocoeliid trematodes of the World fauna.] Publishing House of the Academy of Science of the Kyrgystan SSR Alma Ata, 286 pp. (In Russian) PoJMANSKA, T. (2008): Family Dicrocoeliidae Looss, 1899. In Jones, A., BrAY, R. A., GIBSON, D. I. (Eds) Keys to the Trematoda. Volume 3. London, UK: CABI Publishing and the Natural History Museum London, pp. $233-260$

SADYKHOV, R. D. (1970): [To the knowledge of Fauna of Birds Helminths from Naczekharan district Azerbaian SSR.] Issledovaniya po gelmintofaune Azerbaiana. Baku, Elm, pp. $162-165$

SHTROM, Z. K. (1940): On the fauna of trematode worms from wild animals of Kirghisia. Parasitologicheskii Sbornik ZIN AN SSSR, 8: 189 - 224 (In Russian)

SiTKO, J. (1990): Variability and systematic status of Zonorchis clathratum (Trematoda: Dicrocoeliidae) a parasite of swifts and swallows. Folia Parasitol., 42: 193 - 198

SitKo, J., OKUlEWICZ, J. (2002): Redescription and systematic status of Brachydistomum ventricosum (Rudolphi,1809) comb. n. (Trematoda: Dicrocoeliidae) parasitizing passeriform birds. Helminthologia, 37: 97 - 111

SitKo, J., FAlTÝNKOVÁ, A., SchOlZ, T. (2006): Checklist of the Trematodes (Digenea) of birds of the Czech and Slovak Republics. Praha, Academia, $111 \mathrm{pp}$.

SitKo, J., OKUlEWICZ, J., NoGA, L. (2000): Variability and systematic status of Lutztrema attenuatum (Dujardin, 1845) comb.n. (Trematoda: Dicrocoeliidae) parasitizing passeriform birds. Helminthologia, 37: 97 - 111

SKRJABIN, K. I. (1970): [Family Dicrocoeliidae. Supplement. Trematodes of animals and man. Principles of Trematodology Vol. XXIII]. Nauka, Moscow, pp. 7 - 106 (In Russian)

SkrJabin, K. I., Evranova,V. G. (1952): [Family Dicroceliidae. Trematodes of animals and man. Principles of Trematodology Vol. VII]. Nauka, Moscow, pp. 33 - 604 (In Russian)

Travassos, L. P. (1944): Revisao da Familia Dicrocoeliidae Odhner, 1910. Monographia Instituto Oswaldo Cruz, 2: $1-886$

Yamaguti S. (1971): Synopsis of Digenetic Trematodes of Vertebrates. Vol I., II. Keigaku Publishing, Tokyo, 1074 pp., 349 plates.

Zhelyazkova-Paspaleva, A. (1962): Die in der Gallenbläse des Buteo buteo L. gefundene neue Trematodenart Concinnum butei. Doklady Bulgarskoi Akademii Nauk, 15: 203 - 205 (In Bulgarian)

ACCEPTED SEPTEMBER 26, 2013 